\title{
ALMEIDA, Djaimilia Pereira de. $A$ visão das plantas. São Paulo: Todavia, 2021.
}

Renan Henrique Messias de Paulo

Universidade Federal de São Carlos (UFSCar), São Carlos, São Paulo / Brasil renan.messias@estudante.ufscar.br

http://orcid.org/0000-0002-6909-7328

Recém lançado sob a chancela da editora brasileira Todavia, $A$ visão das plantas, da escritora nascida em Angola e naturalizada portuguesa Djaimilia Pereira de Almeida, já carrega em sua breve trajetória de publicação o segundo lugar do prêmio Oceanos de Literatura de 2020, título este que já fora vencido pela mesma autora em 2019, com a obra Luanda, Lisboa, Paraíso (2018).

Nesta obra, Almeida investe num cenário pós-colonial com uma prosa sublime e profunda. Esta temática do mundo pós-colonial constitui um aspecto recorrente no léxico da nova ficção portuguesa, que se dedica a explorar as consequências de um passado opressor impingido por Portugal aos territórios sob seu domínio, sobretudo os africanos.

Se tivéssemos uma atualização do prático e didático livro $O$ romance português contemporâneo, de Miguel Real, é muito provável que tanto Luanda, Lisboa, Paraíso quanto $A$ visão das plantas se enquadrariam naquilo que o crítico literário denomina como "o espaço romanesco intercontinental" (REAL, 2012, p. 25). Esse espaço, ou melhor dizendo, os espaços explorados na escrita da escritora realçam um olhar atento à história e à consciência social na qual as reminiscências de um passado amargo refletem no cotidiano das personagens construídas pela autora. Assim, o contraste entre o presente e o passado é a matéria com a qual o leitor se depara nesse novo romance. 
Inspirado no personagem homônimo do romance de Raul Brandão, Os pescadores (1923), de onde a autora retira um trecho e o cita como epígrafe, somos apresentados à pacata vida do temido capitão Celestino, um sujeito desprezível em que, no auge de sua carreira no tráfico de escravos em navios negreiros, se tornou reconhecido como um homem perigoso, brutal e violento, mas que no presente da trama, passa o resto de seus dias com a delicadeza das práticas de jardinagem, cultivando com muito afinco e sutileza as suas plantas, com especial destaque às flores, no jardim da abandonada casa de sua família.

Assim, na perspectiva de que o trato com a terra - sujar as mãos, plantar, podar, colher e cuidar - também é um gesto filosófico, ao acompanhar as vivências dum sujeito recluso à espera de sua morte, o leitor sente-se impelido a refletir sobre a própria existência humana da personagem que busca romper com sua filosofia de vida do passado para tentar ser um "novo homem" na senilidade.

No entanto, se "cada ruptura é um recomeço:

[...] Se a ruptura é uma destruição do vínculo que nos une ao passado, uma negação da continuidade entre uma geração e outra, será que podemos chamar de tradição aquilo que rompe o vínculo e interrompe a continuidade?" (PAZ, 2013, p. 15).

Isto pode significar que as continuidades de vivências são interrompidas, mas a noção daquilo que foi vivido e experienciado ainda persiste na memória e na razão do existir.

Ao regressar à casa de sua família para os últimos dias, Celestino atrai olhares de espanto e curiosidade da vizinhança e responde de forma peculiar: "Pressentindo olhares atrás das sebes, Celestino espantava a vizinhança com urros e prometia-lhes a morte" (ALMEIDA, 2021, p. 19). Celestino rompe com o passado brutal, mas ainda carrega consigo as marcas da violência. Sem muito o que fazer, já que vivia sua introspeção no final de sua vida, Celestino passa a cuidar e zelar pelas plantas. A recorrência de "luz e sangue" (ALMEIDA, 2021, p. 40) e as imagens de seu passado ressurgem ao mesmo passo que cuidar das plantas é o contraponto dos atos do ex-capitão. Seja pela luz ou sangue, mar ou terra são explorados na sensível prosa um sujeito conflituoso e contraditório que ganha protagonismo: "As crianças saídas do colégio 
espreitavam os suspensórios de enxada às costas. Seria aquele o diabo? Era forte e espadaúdo, mas tinha tantas flores e tanta paciência para elas" (ALMEIDA, 2021, p. 19).

As inquietações exploradas pela autora representam a marca de uma literatura na qual as chaves de acompanhamento estão na simbiose entre o homem e as plantas, sendo aquele uma figura já corrompida pela vida que levou, e estas o filtro duma mentalidade ingênua, delicada e resistente:

As plantas viam o jardineiro como as plantas veem. Não se sentiam agradecidas. Tratavam o seu regador à semelhança da chuva que caía sobre elas nas noites de Outono. Florescerem não era o seu meio de meterem conversa com o jardineiro, mas uma forma de acentuarem a sua indiferença à declaração de amor que ele cultivava a cada hora. [...] Nenhuma flor lamentava a morte dos escravos que Celestino sufocara no mar. [...] As plantas viam-no como um olho de vidro vê a passagem das nuvens. Ela e o seu amigo eram seiva da mesma seiva, da mesma carne sem dó nem piedade. Atrás das costelas, no lugar do coração, o corsário tinha uma planta (ALMEIDA, 2021, p. 35-37).

As plantas não julgam e não acolhem de livre vontade, elas apenas existem e deixam ser acolhidas e cuidadas.

Outra personagem marcante é o padre Alfredo que, em toda a trama, tenta arrancar confissões de Celestino, a fim de que essa ruptura com seu passado de violência seja melhor demarcada. Mas o único momento em que consegue, de alguma forma, lavrar o espírito do ex-capitão é com a morte do protagonista que, com sua quase cegueira total - subtendida aliás como um afastamento do sentimento de culpa e das atrocidades cometidas- , reconstrói a imagem daquele que deixou de ser um diabo, que passou por jardineiro e, por fim, foi enxergado, por todos, inclusive pelas plantas, como um herói:

"Se alguém, alguma coisa, no Céu, tivera piedade do monstro que fora e que era, revelava-o sob a forma de flores e frutos, mostrando-se como uma graça que só ao capitão cabia regar" [...] Anos depois de ter regressado, 
os que haviam sabido do capitão Celestino de volta tinham morrido. [...] Lembravam-no como a um herói remoto e não como o velho que ainda vivia na casa da rua dos choupos. Os rumores sobre o seu passado feroz eram já cantigas de pescadores quando, numa noite de Inverno, acabou os seus dias, sem uma dúvida na consciência tranquila. [...] À saída de casa, a visão das plantas pareceu-lhe uma aleluia pela passagem da alma do capitão. As rosas, os cravos, os abetos, a ameixoeira ainda não sabiam que o seu amigo tinha morrido. [...] Nas suas mãos pias, todas as plantas morriam (ALMEIDA, 2021, p. 63-85).

Sem querer roubar o prazer da leitura ao leitor, $A$ visão das plantas merece atenção em virtude de uma sensibilidade poética, expressa nas oitenta e cinco páginas da obra, e que marca um projeto de criação potente de Djaimilia Pereira de Almeida. Ela também, como uma espécie de jardineira delicada, rega os leitores com uma reflexão detida sobre as tensões, rupturas, ressignificações e, sobretudo, a visão daqueles que não exprimem ações, mas partilham sentimentos. Apensar de curto, não será demais afirmar que $A$ visão das plantas é uma obra de grande relevância para a literatura angolana, de língua portuguesa e mesmo universal, já que diz muito sobre o ser humano e suas rupturas.

\section{Referências}

ALMEIDA, Djaimilia Pereira de. A visão das plantas. São Paulo: Todavia, 2021.

PAZ, Octavio. Os filhos do barro. Do romantismo à vanguarda. Tradução de Ari Roitman e Paulina Wacht. São Paulo: Cosac Naify, 2013.

REAL, Miguel. O romance português contemporâneo (1950-2010). Lisboa: Caminho, 2012. 